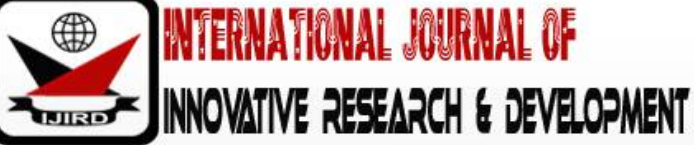

ISSN 2278 - 0211 (Online)

\section{Copping with the Menance of Environmental Deterioration in Urban Slum Areas within Jos Metropolis, Nigeria}

\author{
Emmamoge Orewere \\ Lecturer, Department of Horticulture and Landscape Technology, \\ Federal College of Forestry, Jos, Plateau State, Nigeria \\ Michael Olabode Ogunrayewa \\ Senior Lecturer, Department of Architecture, University of Jos, Nigeria \\ Dr. Ayodele Owonubi \\ Lecturer, Department of Horticulture and Landscape Technology, \\ Federal College of Forestry, Jos, Nigeria
}

\begin{abstract}
:
The Sustainable Development Goals adopted by the United Nation of ending poverty and hunger (goal one), provision of clean water and sanitation (goal six) and sustainable cities and community's development (goal eleven) targeted for year 2030 and Nigeria's Vision 20:2020 (NV 20:2020) Economic Transformation Blueprint cannot be overemphasized. Slums the places where poor people struggle to make aliving and bring up their families, and the places where about one third of the world's urban population live. Slums are neglected parts of cities where housing and living conditions are appallingly poor. The study examined urban slum growth and how they contribute to environmental deterioration within the city. Slums are characterized by existence of poor environmental control with stagnant waste water in generally dirty and unclean living environments, overcrowding, loss of green areas, environmental pollution, dilapidated structures, land degradation, flooding amongst other. The study area is Anguwan Rogo located in Jos North Local Government Area of Plateau State, Nigeria. Data for this paper is gathered through physical site survey, case study and the review of related literature. The paper submits by way of conclusion that rehabilitation; planning and implementation should be inclusive of the input of urban designers working closely with slum dwellers, governments and other relevant stakeholders to ensure that prevalence of slums is reduced to the barest minimum and sustainable development is ensured.
\end{abstract}

Keywords: Copping, environmental deterioration, Jos metropolis, urban slums, plateau state

\section{Introduction}

Slums the places where poor people struggle to make aliving and bring up their families, and the places where about one third of the world's urban population live. (The challenge of slums: global report on human settlements, 2003)

The importance of maintaining a healthy and sustainable environment cannot be overemphasized.The UNHABITAT (2012), defines slum as any specific place, whether a whole city or a neighborhood, more than half of all households lack improved water, improved sanitation, sufficient living area, durable housing, secure tenure or combinations of two. Recently as maintained by Cities Alliance Action Plan (1999), slums are neglected parts of cities where housing and living conditions are appallingly poor. The case study conducted in Chengdu; China defined slums as "shanties in low-lying areas". Slums are home to the poorest of urban populations in Africa. The houses inhabited by slum dwellers are mostly decrepit, overcrowded, in neighborhoods that are prone to flooding \&beset with poor sanitation \& shortage of portage water (Emma-Ochu, et al., 2016).They are areas which little government attention in terms of provision or maintenance of public facilities and infrastructure is being felt. These are high- density squalid central city tenements to spontaneous squatter settlement without legal recognition which sprawl at the edge of cities.

Currently, about 1 billion people live in slums, with most slum dwellers located in less developed countries, which accounts for about $30 \%$ of their urban population. The number of slum dwellers is projected to increase to 2 billion by 2030 and to 3 billion by 2050 if current trends persist (UN-Habitat, 2010; United Nations, 2015a), as cited by Mahabir,et al.,(2016).Available data reveal that the population of Nigeria has been increasing at an alarming rate. Our towns and cities are growing rapidly. The current urbanization rate of Nigeria is 5.5 percent per annum and the urban population was put at 50 percent in 2012 (Pepple, 2012a) as cited by Mallo, et al., (2015).The slum situation in Nigeria is already frightening for the reason that the proportion of people affected by slum conditions is such a significant element in sub-Sahara Africa. In 2012, the estimated population of 47 sub-Sahara African countries was 910.4million and of this, 167million were Nigerians. Of the 167million people in Nigeria, 61.1 percent were said to reside in slums (World Bank, 2013; FRN-National Population Commission, 2013; Pepple, 2012a) as cited by Mallo, et al., (2015). 
Most slums in Nigeria developed as a result of high urbanization pace leading to conglomeration of people in the urban centres without prior plans, most especially from the second half of the last century. Development of slums in Jos however inclined a bit from this generalized origin as it originated from the economic growth of the city which generated continual migration of labourers and traders from the North and South of the country into the booming tin mining region at the wake of twentieth century; thereby leading to development of sub-standard, unplanned and uncontrolled housing. The settlements continued to develop, especially in the areas reserved for traditional settlements, with limited management and control thereby generating environmental deterioration, inadequate housing and poor infrastructure, hence the growth of slum areas at the different locations in the city Oladosu, et al., (2015).

Heilbrun, (2001), as cited by Ogunrayewa, (2010) points out that the wealth and development of any nation have been consistently tied to the standard of living and the environmental conditions of her entire citizenry. Dumping of refuse on unkempt environments, poor road network, lack of proper refuse disposal, smoke from refuse burning are very ubiquitous in most Nigerian cities. The inadequate provision of such basic infrastructure coupled with unplanned development control measures by planning agencies and unprecedented population surge of slum poses a threat to environment quality and health of slum dwellers. The purpose of this research is to analyze the menace of environmental deterioration within Anguwan Rogo slums area of Jos metropolis.

\subsection{Objectives of the Study}

The objectives of the study are as follows:

- To provide a safe, healthy, pleasant, socially functional living and working environment.

- To develop an approach for a successful Slum Eradication

- To provide information which will aid in the creation of a functional community and creation of good buildings which will reduce the growth of slums.

\subsection{Research Questions}

- How can the environment be planned to provide a safe, healthy, pleasant, socially functional living and working environment?

- What approach can be taken for a successful slum eradication programme to be effective?

- What kind of information which will aid in the creation of a functional community and creation of good buildings thereby mitigating the prevalence of slum growth?

\section{Literature Review}

\subsection{The Concept of Slums}

Slums are a group of buildings characterized by the deterioration, unhygienic sanitary condition endangering health, safety or morals of its inhabitants (UN, 1952), as cited by Chattopadhyay, et al., (2010). A compact area of at least 300 populations or about 60-70 households of poorly built congested tenements, in an unhygienic environment usually with inadequate infrastructure and lacking in proper sanitary and drinking water facilities (Chattopadhyay, et al., 2010).Recently as maintained by (UN-Habitat, 2012), slumsare urban areas that are heavily populated and have substandard housing with very poor living conditions, creating several problems.

Slums range from high-density, squalid central city tenements to spontaneous squatter settlements without legal recognition or rights, sprawling at the edge of cities. Slums have various names, favelas, kampungs, bidonvilles, tugurios, yet share the same miserable living conditions. Slums are not static; there are ongoing dynamics that, over a period of years, may turn an established urban area into a slum or that may lead to the redevelopment of an existing slum (The challenge of slums: global report on human settlements, 2003).Slums arise from poor people's need to find affordable and accessible housing. They are created by the market or by the people themselves when increasing numbers of people in poverty meet inadequate housing and planning responses. Slum conditions are worsened by economic decline, increasing inequality, loss of formal-sector jobs, rapid immigration, poor governance and exclusionary actions (The challenge of slums: global report on human settlements, 2003).

Likewise, slum dwellers are not a homogeneous population, but a diverse group of people with different interests, means and backgrounds. Slums are also a significant economic force and represent disadvantaged communities continuing to have large impact on the physical and economic landscapes. In many cities, as much as 60 percent of employment is in the informal sector of the urban population.

Today, more than one billion people in the world live in slums. In the developing world, one out of every three people living in cities lives in a slum (Morakinyo, et al., 2012). According to Arimah, (2001), Nigeria is ranked as one of the countries with high slum occurrence (see Table One). A recent projection indicates that more than 60 percent of Nigerians will live in urban centres by 2025, and a sizeable proportion (mostly low-income earners and the poor) of these are likely to live in slums if action is not taken (FGN - MDG Report, 2010), as cited by Mallo, et al., (2015).The slum situation in Nigeria is already frightening for the reason that the proportion of people affected by slum conditions is such a significant element in sub-Sahara Africa.

The increase of shanty dwellings, squatter settlements and slums in most of our cities in Nigeria and other less developed nations of the world is attributed to a chain of factors. Of course, such factors are closely associated with the low level of socio-economic and cultural lifestyles of the inhabitants (Omole, 2010). Slums are areas that concentrate lowincome earners, low-cost houses, possibly mud houses, no layout and poor inhabitants. 


\begin{tabular}{|c|c|c|c|}
\hline Country & $\begin{array}{c}\text { Slum Annual Growth } \\
\text { Rate (\%) }\end{array}$ & $\begin{array}{c}\text { Slum Population } \\
\text { (Thousands) }\end{array}$ & $\begin{array}{c}\text { Scenario 2020 with no } \\
\text { change }\end{array}$ \\
\hline Angola & 5.28 & 3,918 & 10,677 \\
\hline Kenya & 5.88 & 7,605 & 23.223 \\
\hline Nigeria & 4.96 & 41,595 & 76,749 \\
\hline South Africa & 0.19 & 8,376 & 8,677 \\
\hline Uganda & 5.32 & 3,241 & 8,904 \\
\hline Tanzania & 6.16 & 11,031 & 35,561 \\
\hline Brazil & 0.34 & 51,676 & 55,074 \\
\hline El Salvador & 1.89 & 1.386 & 1,986 \\
\hline
\end{tabular}

Table 1: Slum Growth in Developing Countries

Source: UN-Habitat, Urban Observatory, 2007, as Cited in Lekwot, Et Al., 2015

\subsection{The Characteristics of Slums}

A review of the definitions used by national and local governments, statistical offices, institutions involved in slum issues and public perceptions reveals the following attributes of slums.

\subsubsection{Lack of Basic Services}

Lack of access to sanitation facilities and safe water sources is the most important feature, sometimes supplemented by absence of waste collection systems, electricity supply, surfaced roads and footpaths, street lighting and rainwater drainage (The challenge of slums: global report on human settlements, 2003).

\subsubsection{Substandard Housing or Illegal and Inadequate Building Structures}

Many cities have building standards that set minimum requirements for residential buildings. Slum areas are associated with a high number of substandard housing structures, often built with non-permanent materials unsuitable for housing given local conditions of climate and location. Factors contributing to a structure being considered substandard are, for example, earthen floors, mud-and-wattle walls or straw roofs. Various space and dwelling placement bylaws may also be extensively violated (The challenge of slums: global report on human settlements, 2003).

\subsubsection{Overcrowding and High Density}

Overcrowding is associated with a low space per person, high occupancy rates, cohabitation by different families and a high number of single-room units. Many slum dwelling units are overcrowded, with five and more persons sharing a one-room unit used for cooking, sleeping and living. Bangkok requires at least 15 dwelling units per rai (1600 square metres) (The challenge of slums: global report on human settlements, 2003).

\subsubsection{Unhealthy Living Conditions and Hazardous Locations}

Unhealthy living conditions are the result of a lack of basic services, with visible, open sewers, lack of pathways, uncontrolled dumping of waste, polluted environments, etc. Houses may be built on hazardous locations or land unsuitable for settlement, such as floodplains, in proximity to industrial plants with toxic emissions or waste disposal sites, and on areas subject to landslip. The layout of the settlement may be hazardous because of a lack of access ways and high densities of dilapidated structures (The challenge of slums: global report on human settlements, 2003).

\subsubsection{Insecure Tenure; Irregular or Informal Settlements}

A number of definitions consider lack of security of tenure as a central characteristic of slums, and regard lack of any formal document entitling the occupant to occupy the land or structure as prima facie evidence of illegality and slum occupation. Informal or unplanned settlements are often regarded as synonymous with slums. Many definitions emphasize both informality of occupation and the non- compliance of settlements with land-use plans. The main factors contributing to non-compliance are settlements built on land reserved for non-residential purposes, or which are invasions of nonurban land (The challenge of slums: global report on human settlements, 2003).

\subsubsection{Poverty and Social Exclusion}

Income or capability poverty is considered, with some exceptions, as a central characteristic of slum areas. It is not seen as an inherent characteristic of slums, but as a cause (and, to a large extent, a consequence) of slum conditions. Slum conditions are physical and statutory manifestations that create barriers to human and social development. Furthermore, slums are areas of social exclusion that are often perceived to have high levels of crime and other measures of social dislocation. In some definitions, such areas are associated with certain vulnerable groups of population, such as recent immigrants, internally displaced persons or ethnic minorities (The challenge of slums: global report on human settlements, 2003).

\subsubsection{Minimum Settlement Size}

Many slum definitions also require some minimum settlement size for an area to be considered a slum, so that the slum constitutes a distinct precinct and is not a single dwelling (The challenge of slums: global report on human settlements, 2003). 


\subsection{Growth of Slums in Jos}

It is pertinent to note that following the creation of 12 states by the General Gowon's regime in 1967 which saw the creation of Benue Plateau State, there was also an influx of people all over the Benue and Plateau axis as well as fromthe North West and North east of Nigeria in search of either employment or commerce. This brought about high population pressure that necessitated the growth of slum settlements such as Gada Biyu, Tudun Wada, Angwan Rukuba, Jenta, Nasarawa Gwong and Congo Russia (See Table 2). Of all these slums, Tudun Wada was the most prominent because of its proximity to the state secretariat for those of them that were in the civil service, this was the most promising location to take advantage of (Fwatshak and Dugga, 2011; Ajiji and Larab, 2016).

Another epoch in the growth of slum settlements in Jos was the inferno that engulfed the Jos Central market (Kasuwan Kantoma) in February 1974 where the market was completely burn down. At that time, the best the government thought of was that while it needed to set machinery in motion to build an ultra-modern market that would span within the period of ten years, traders that lost their shops and belongings needed to be compensated and given free land to ameliorate their suffering and hardships(Ajiji and Larab, 2016). Consequently, lands at Rikkos new layout and Angwan Rogo were given out to the traders as compensation. However, most traders sold out the plots that were offered to them and in the course of time, these locations evolved into slums that would eventually constitute flash points as far as the history of violence and conflicts in Jos is concerned (Ajiji and Larab, 2016). Chains of religious violence from Kano, JimetaJalingo, Kafanchan- and Bauchi in December 1980, led to forceful migrations to safer places and since Jos appeared to have been the most peaceful town in the north, all roads led to Jos.

This also resulted in the high population build-up in the slums of Jos particularly Angwan Rogo, Rikkos Bauchi Road, Ali Kazaure and other Hausa/ Fulani dominated areas as far as the Muslim are concerned (See Table 2). For the fleeing Christians, they had to move to the Christian dominated slums like Angwan Rukuba, Tudun Wada, Jenta, Gada Biyu and Congo Russia (Ajiji and Larab, 2016).Again because of the proximityof Kafanchan to Jos, another wave of migrations took place to add to the population pressure of the slums in Jos town.

\begin{tabular}{|c|c|c|}
\hline S/ No & Nigerian Cities & Slum Areas \\
\hline 1. & Lagos & Ajegunle, Makoko, Agege, Bariga, Badia, Illaje, Ijeshatedo/ Itire, \\
Iwaya, Amukoko
\end{tabular}

Table 2: Slum Prevalence in Nigerian Cities

Source: Adapted from Sunday A. B. \& Alexander A. F., 2011 Field Work

\subsection{Types of Slums and Location in Jos Metropolis}

The slums in Jos arise from the absence of effective spatial planning and development control (Mallo, et al., 2015). Slums vary very widely in terms of their location, spatial forms and socio-economic and environmental characteristics. It could be argued that no two slums are the same as they differ in their history, growth and development, opportunities and challenges (Dung-Gwom, 2007).The slums residents are marginalized around open mining ponds and rocky areas. 


\begin{tabular}{|c|c|c|c|}
\hline S/ No & Central Areas Slums & Intermediate Slums & Peripheral Slums \\
\hline 1 & Gangare & Tudun Wada & Zarmaganda \\
\hline 2 & Sarkin Arab & Sabon Gari- Tudun Wada & Dadin Kowa \\
\hline 3 & Abba Nashehu & Dogon Karfe/ Abattoir & Old Lamingo Road (Ito Baba) \\
\hline 4 & Sarkin Mangu & Anguwan Rukuba & Yan Trailer \\
\hline 5 & Garba Daho & Rikkos & \\
\hline 6 & & Nasarawa & \\
\hline 7 & & Congo Russia & \\
\hline 8 & & Jenta Adamu & \\
\hline 9 & & Jenta Makeri & \\
\hline 10 & & Jenta Mangoro & \\
\hline 11 & & Jenta Apata & \\
\hline 12 & & Laranto & \\
\hline 13 & & Anguwan Rogo & \\
\hline 14 & & Kabong & \\
\hline 15 & & Rosso & \\
\hline
\end{tabular}

Table 3: Location of Slums Areas in Jos

Source: Adapted from Dung-Gwom, 2007

\subsection{Environmental Deterioration among Urban Poor}

The Advanced English Dictionary Offline, defines Environmental Deterioration as the process of changing to an inferior state within the surroundings. It is also defined as the deterioration of the natural environment through human activities and natural disasters United Nations, (1997). Heilbrun, (2001), as cited by Ogunrayewa, (2010)points out that the wealth and development of any nation have been consistently tied to the standard of living and the environmental conditions of her entire citizenry. Dumping of refuse on unkempt environments, poor road network, lack of proper refuse disposal, smoke from refuse burning are very ubiquitous in most Nigerian cities.

Earlier studies like that ofTipping et al.,(2005);Paterson et al., (2007),as cited by Babanyara,et al.,(2010), indicate that in developing countries, $40 \%$ to $60 \%$ of urban dwellers have inadequate sanitation, and slum-dwellers (urban poor) are the most vulnerable to sanitation-related diseases because they are the most exposed to unmanaged human excreta and waste. Nigerian cities of today face numerous problems these include urbanization, deteriorating environment, urbandecay, un-cleared refuse, flooding, erosion and pollution (Babanyara,et al., 2010).

In a more recent studies conducted by Ajayi et al., (2014) the urban poor in developing countries find land in the city to live and build their own houses. If possible, they construct their toilet and drainage system. They tap electricity from an adjacent house through an informal connection and if they are threatened with eviction, they find another place to live. They work in irregular and low-paid jobs, and develop and operate micro-enterprises to make a living. They organize their savings and loans groups so that they can make investments in housing or business. They produce and sell goods and services to each other in quantities and quality for which there is a demand among the poor. The urban poor show a great ingenuity in finding solutions to their problems and meeting their basic needs. These solutions most often result into environmental problems inform of sub-standard housing, poor waste disposal system, poor environmental sanitation and degradation among others.

There is the problem of environmental pollution which is rapidly increasing in Nigeria. The major causes of the increase include poor sanitation, inadequate solid waste disposal, effluent discharge, rapid and unplanned urbanization, mining, and increasing use of chemical fertilizers and insecticides. Surface runoffs collect all types of excreta and these are moved into the rivers, dams and sometimes into wells (Babanyara, et al., 2010). Sanitary facilities like sewers, sewage treatment facilities, septic tanks and toilets for home are known to be grossly inadequate in Nigeria and have worsened over the years due to rapidrate of urbanization in the country (Babanyara, et al., 2010).

Other forms of deterioration amongst the urban poor include erosion, flooding, water pollution, damaged sanitary facilities. It is worth noting that poor housing conditions due to lack of maintenance can have negative effect on the health of occupants.

\section{Methodology}

\subsection{Source of Data}

Data was drawn from primary and secondary sources. The secondary data involves the use of information already in existence and this was sourced largely through literature review. Primary data used was acquired through field survey, and case study.

\subsection{Research Method}

The research method employs the descriptive and case study research method on various slum settlement so as to obtain data to be used in carrying out the research. The case study method was adopted so as to study existing settlement within Anguwan-Rogo with a view to extract relevant data from them while the descriptive method uses the data so obtained to provide deep insight into the phenomena of slum settlement. 


\subsection{Topography of Jos Plateau}

Plateau state is located in Nigeria's middle belt with an area of $26,899 \mathrm{~km} 2$. The state has an estimated populated of about three million people. The state is named after the picturesque Jos Plateau. A mountainous area is the north of the state with captivating rockformation. Bare rocks are scattered across the grasslands, which cover the Plateau. The altitude ranges from around 1,200meter (about 4000 feet) to a peak of 1,829 meters above sea level in the shore hills ranges near Jos (Rengel, 2003) as cited by Ugorji, (2018).Figure 1 shows the location of Plateau State in Nigeria while Figure 2 and 3 shows the map of Plateau State and Jos respectively.

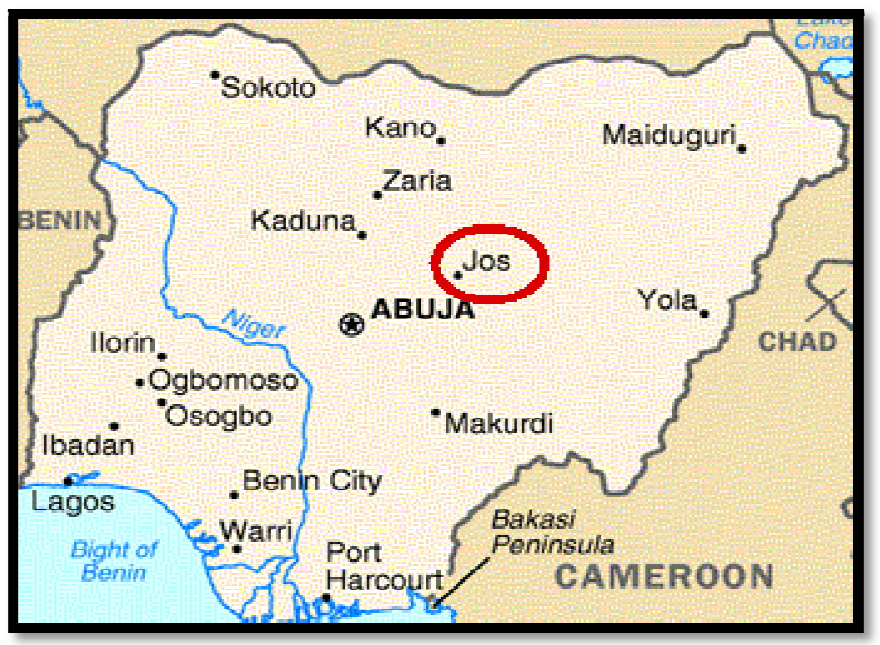

Figure 1: Map of Nigeria Showing Jos, Plateau State Capital in Sphere Source: Http:// Www.Plateaustategov.Org/ Visit/ Jos.Html

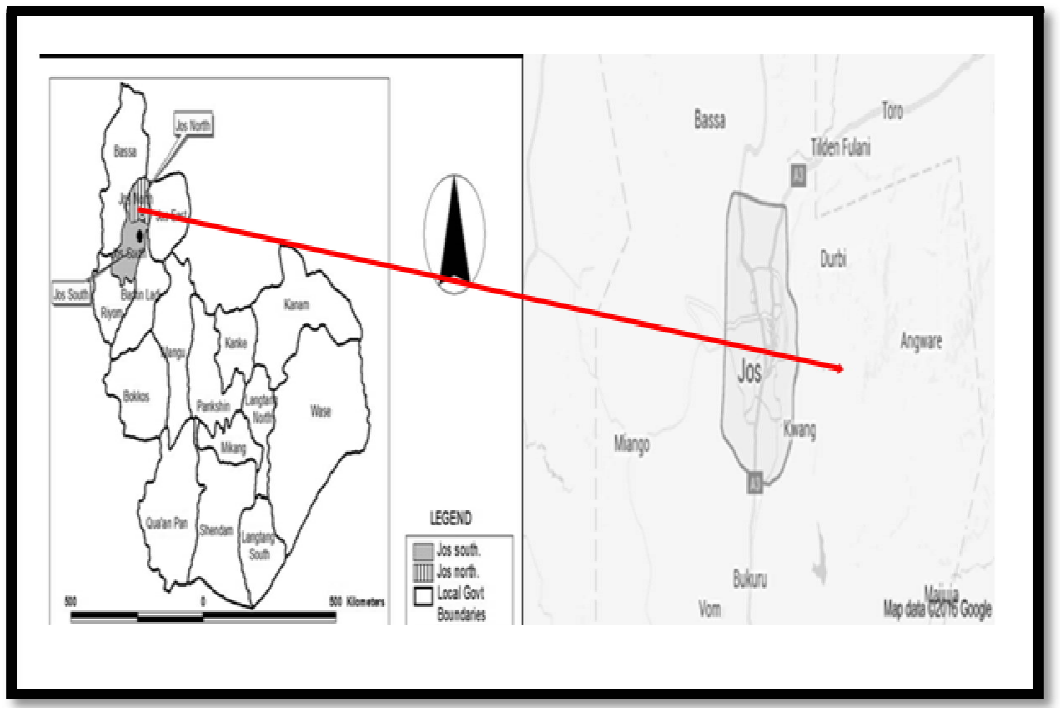

Figure 2: Jos Metropolitan Local Government Areas Map of Jos

Source: Adapted from Okoronkwo, 2017, Adapted from Okoronkwo, 2017

\subsection{Case Study - Anguwan-Rogo}

This study adopted the interview and case study methodology to examine one of the populated slums in Jos. Anguwan Rogo, a predominantly Muslim area near the University of Jos (Human Rights Watch interview, Jos, October 4, 2001). Angwan Rogo is south of Zaneri, southeast of Layi Russo and east of Rafin Par (https:// mapcarta.com).It lies on latitude $9^{\circ} 56^{\prime} 47 \mathrm{~N}$ and longitude $8^{\circ} 53^{\prime} 12 \mathrm{E}$ with an altitude of $1276 \mathrm{~m}$ (www.fallingrain.com > World > Nigeria > Plateau). A high-density residential area with a total of 3,980 units as at 2014 (Rasheed et al, 2015). A cursory observation reveals it is beset with severe environmental problems. Water and air pollution and poor sanitation take a heavy toll on the quality of life of city residents, impacting the urban poor most severely. It is accessed through the Bauchi Road and the Bauchi Ring Road with poor setbacks and airspaces which would have helped in curbing the effect of fire outbreaks. Their main occupation is trading in the formal and informal sectors. Figure 3 highlights the study area of Angwan Rogo within Jos metropolis and Figure 4 show the location to the study area. 


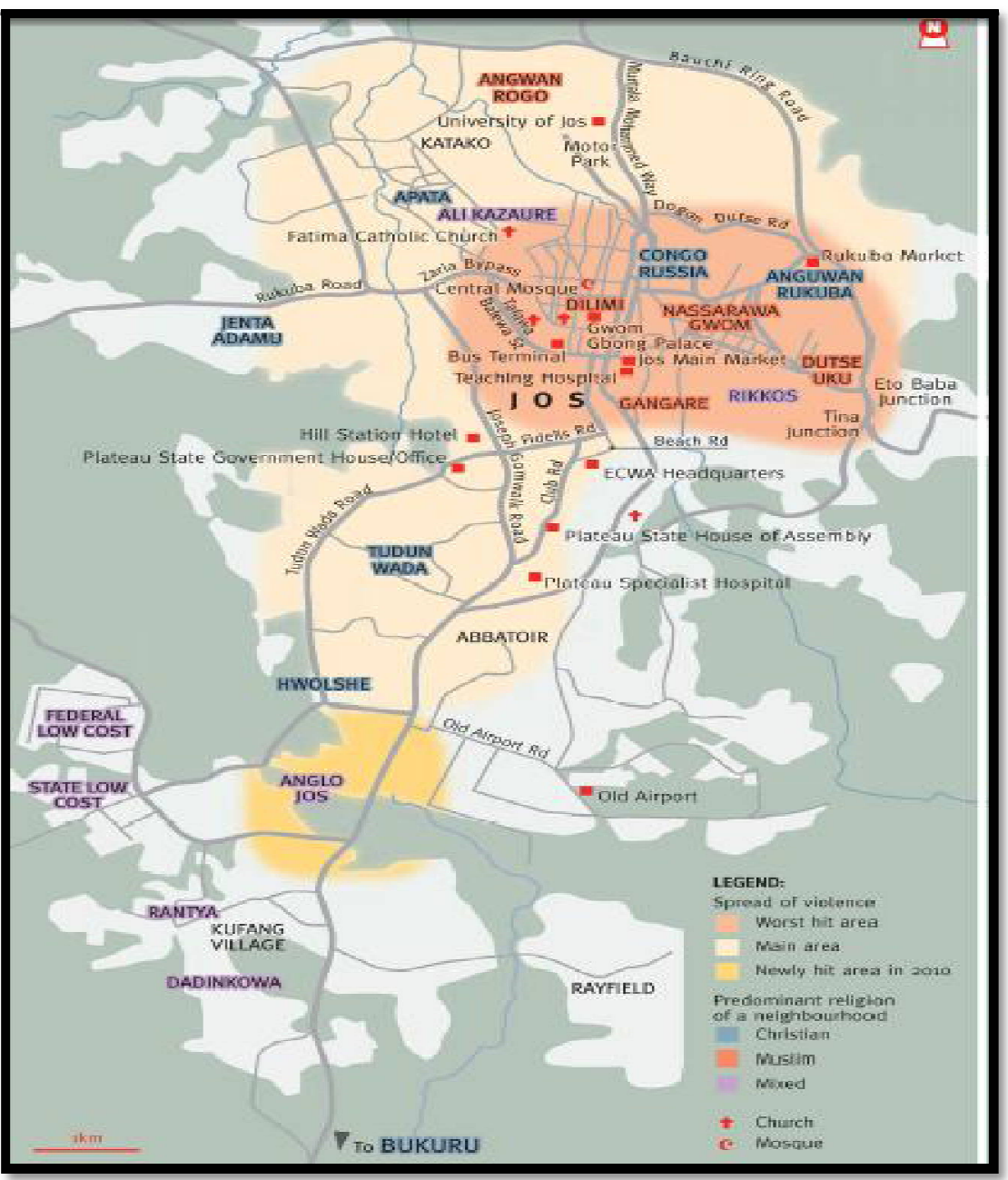

Figure 3: Map of Jos Metropolis Showing Study Area at the Top Source: Adapted from Lekwot, Et Al., 2015

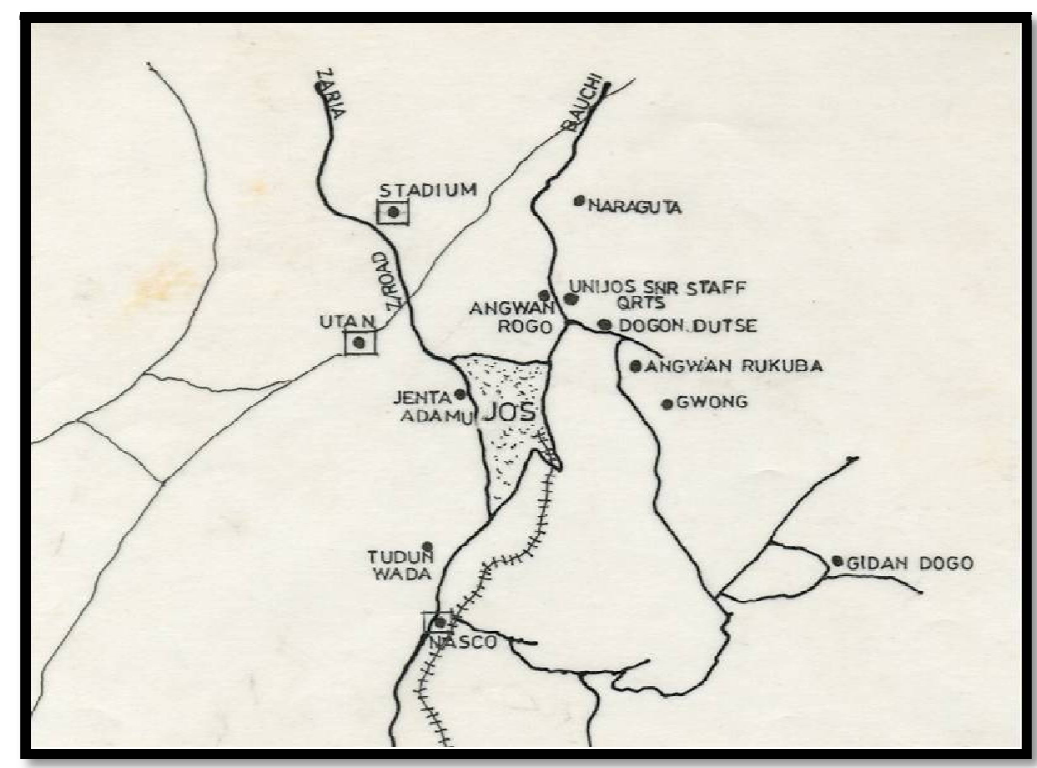

Figure 4: Map Showing the Study Area (Anguwan Rogo) in Jos North Source: Pubs.Sciepub.Com, 2018

\section{Discussion of Findings}

Photographic illustrations of present situation of Angwan Rogo Slum Settlement, Jos. Findings from the study are as discussed under the various sub-headings which isevident from Plates i to $\mathrm{x}$.

\subsection{Physical Environment}

Houses are juxtaposed on a sloppy terrain making the vista of the environment unorganized, unplanned, overcrowded and lacking in basic amenities and infrastructure (Abubakar, 2014). Significant environmental problems; 
including air and water pollution from houses especially waste water, oil and local shops. What should be obtained is that planning authorities should establish environmental acts, which aids uniform processes for assessing the potential environmental impacts of new developments. Figure 5 shows the physical environment (Figure 5)

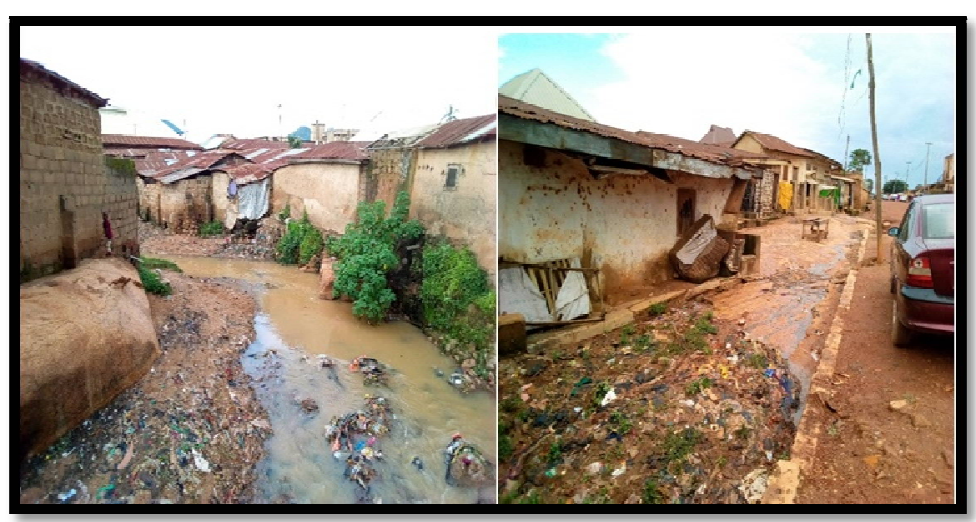

\subsection{Roads and Accessibility}

Figure 5: Clustered Houses with Rocky Terrain of Road Network. Source: Author's Field Survey, 2018

This settlement is accessed through the Bauchi Road and the Bauchi Ring Road with poor setbacks and airspaces which would have helped in curbing the effect of fire outbreaks. Roads that exist in this town are predominantly service/ feeder roads which are accessed directly from houses, shops and worship ground. Road widths are less than four meters, untarred and sandy. Roads are seen to meander at different points and corner due to the topography of the land which has lots of rock outcrops. Footpaths and walkways are seen not to be defined (Figure 6 \& iii)

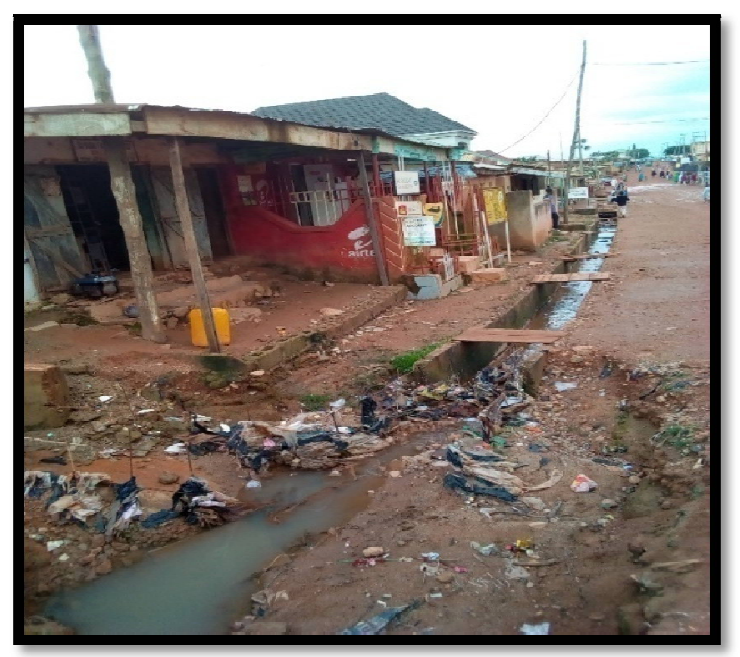

Figure 6: Accessibility to the Slum Settlement

Source: Author's Field Survey, 2018

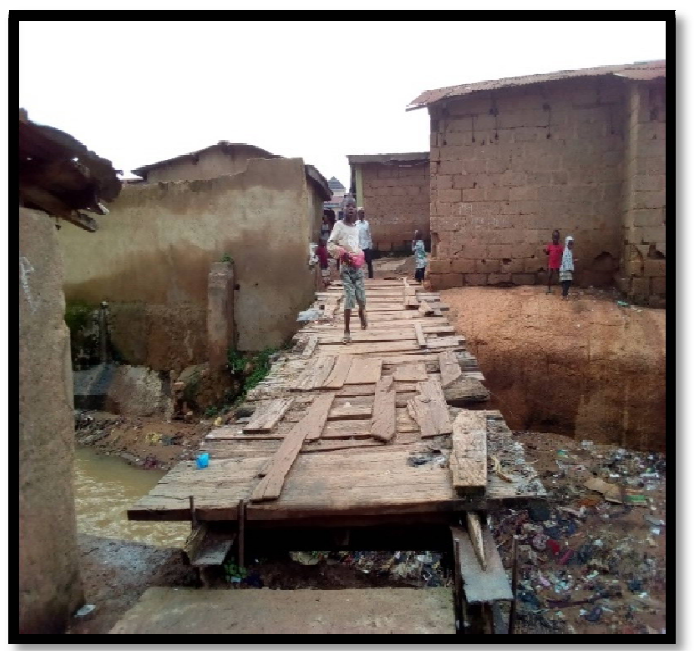

Figure 7: A Man-Made Bridge Used as Entry into the Area Source: Author's Field Survey, 2018 


\subsection{Environmental Deterioration and Pollution}

\subsubsection{Water Quality}

A cursory observation reveals that lack of sanitation and sewerage systems has a dramatic impact on urban watercourses (Figure 8). Access to safe drinking water is unstable in this settlement. Residence dispose of all their wastes from homes and commercial businesses. Wastewater from human settlements contains organic material and nutrients; industrial wastewater $\mathrm{p}+$-contains many different types of toxic pollutant. Some of the residents defecate and urinate in the stream and still fetch the same water to use for domestic purposes. These make the water unsafe for humans to use for many purposes including drinking and irrigation, as well as harming the fish and other animals and plants living in the water. Any changes to the quality of surface water also affects groundwater because they are linked by the processes of the water cycle so pollutants from the surface will infiltrate down and contaminate soil and groundwater as well.

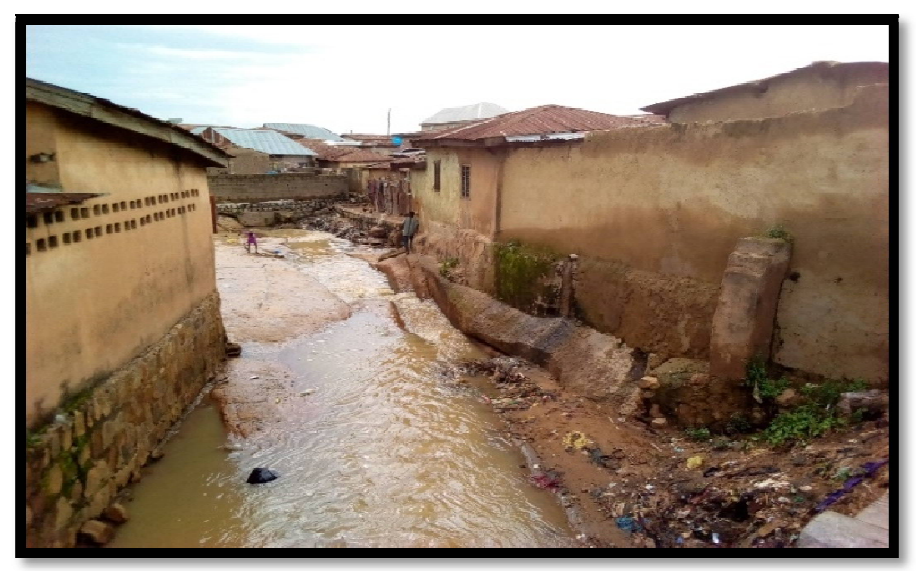

Figure 8: Liquid Waste Disposal Flowing Into the Streams in Anguwan Rogo

Source: Author's Field Survey, 2018

\subsubsection{Solid Waste}

In Anguwan Rogo the solid waste management is inefficient, often ends up in illegal dumps on streets, open spaces, wastelands, drains or rivers.This can lead to the pollution of groundwater and surface waters which may be used as a source for drinking water. Also, there is the problem of widespread environmental deterioration and pollution through burning of solid wastes (Figure 9).

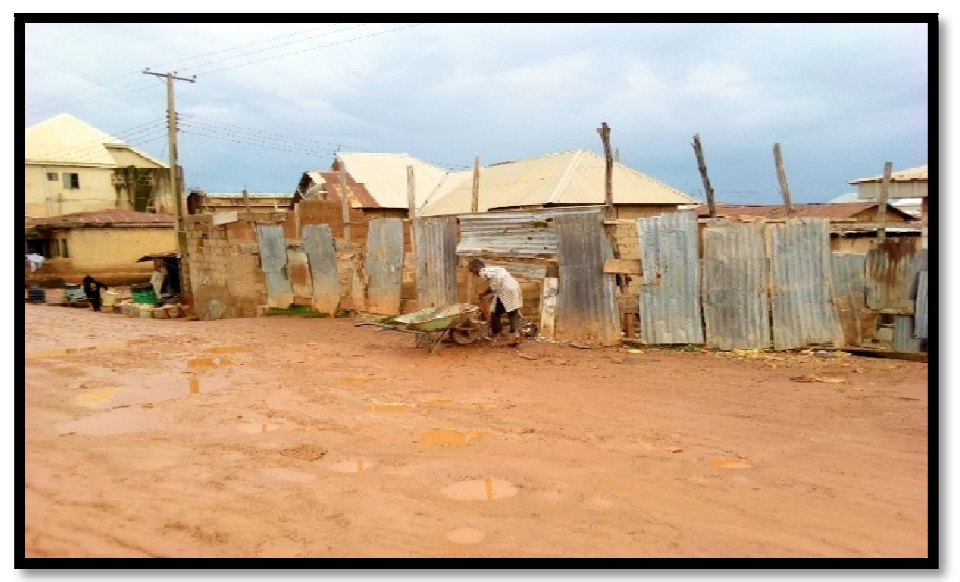

Figure 9: A Boy Dumping Solid Waste into the Flowing Stream Source: Author's Field Survey, 2018

\subsection{Sanitation and Drainage Services}

The sanitation services and waste management are extremely poor and deplorable. Waste water flows directly in front of the houses (Figure 10) and have become breeding grounds for vector agents i.e. mosquitoes. Drainage facilities are deplorable, non-functional or are operating below capacity. Other issues with the system include frequent blockage of sewer lines and leakage of untreated sewage into local streams and rivers. 


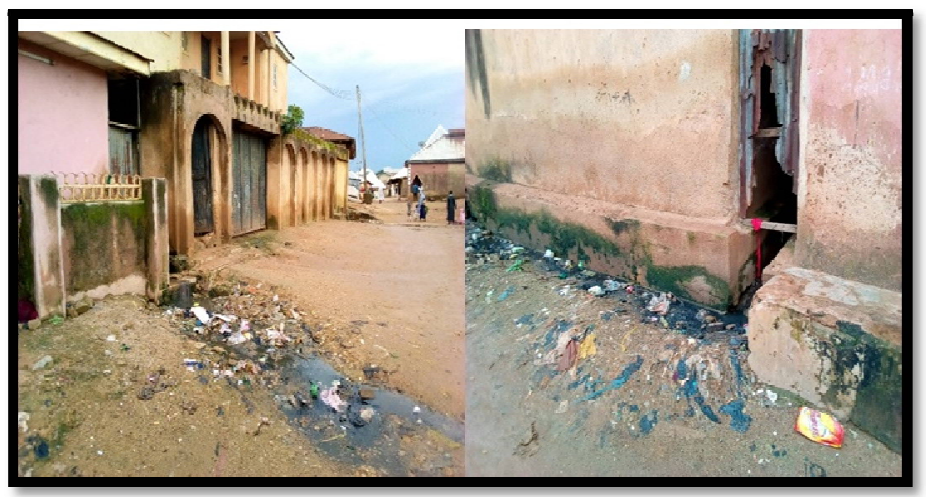

Figure 10: Liquid Effluents In Front Of Some Houses Source: Author's Field Survey, 2018

\subsection{Social Amenities}

\subsubsection{Electricity}

The location of high-tension electric pole in front of the house can lead to electrocution of the inhabitants. No observed set-back to electric power line (Figure 11).

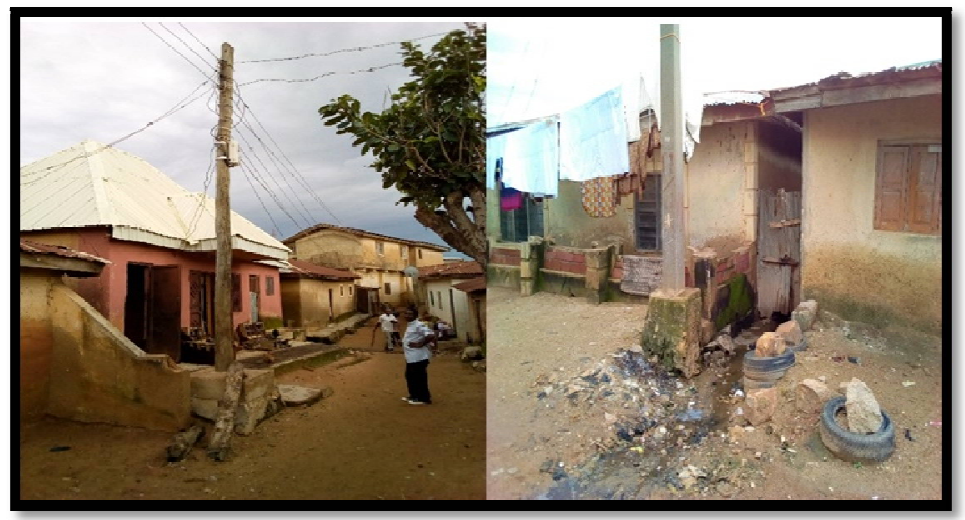

Figure 11: Location of High-Tension Power Line in Front of Houses Source: Author's Field Survey, 2018

\subsubsection{Water}

Existing piped water connection is blocked, residents in this community have little hope of getting piped water in the near future. Thus, water vendors and boreholes are the main source of water for domestic use in these areas. Residents here live without access to safe drinking water and proper sanitation (Figure 12 \& ix).

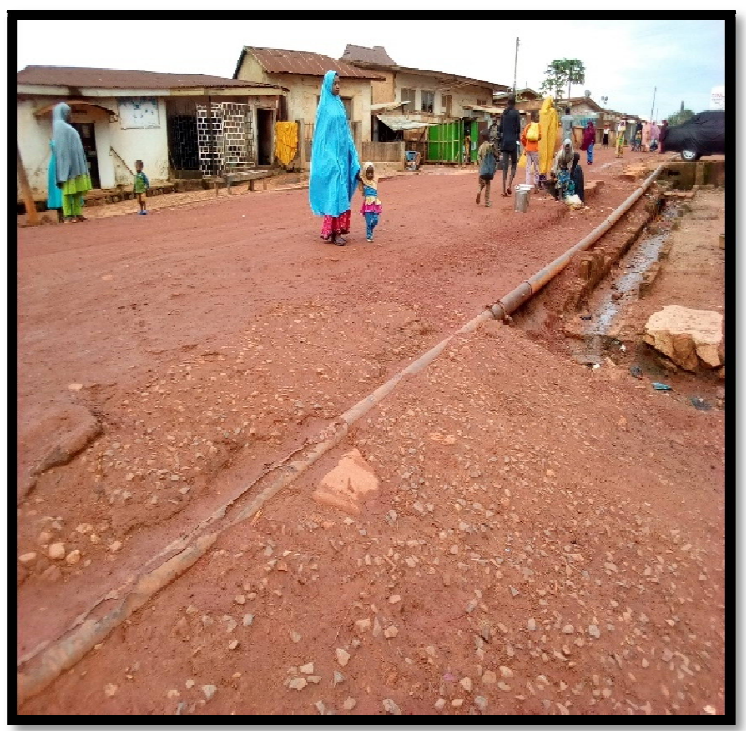

Figure 12: Blocked Water Pipe Filled with Sand Source: Author's Field Survey, 2018 


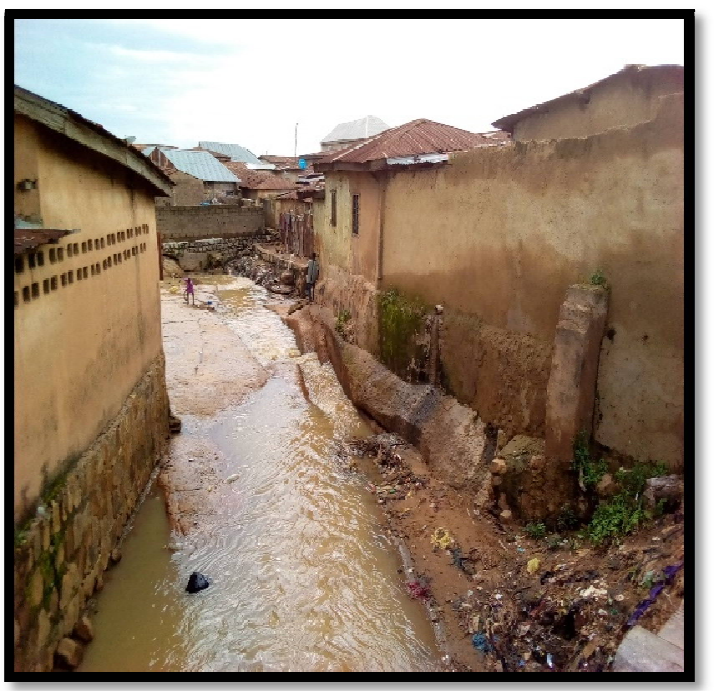

Figure 13: Flowing Water with Waste in It Source: Author's Field Survey, 2018

\subsection{Trading}

Trading activities of food items on trays and in buckets is done close to the deplorable drainage conditions on the road, within the slum area thereby preventing proper usage of the road network (Figure 14).

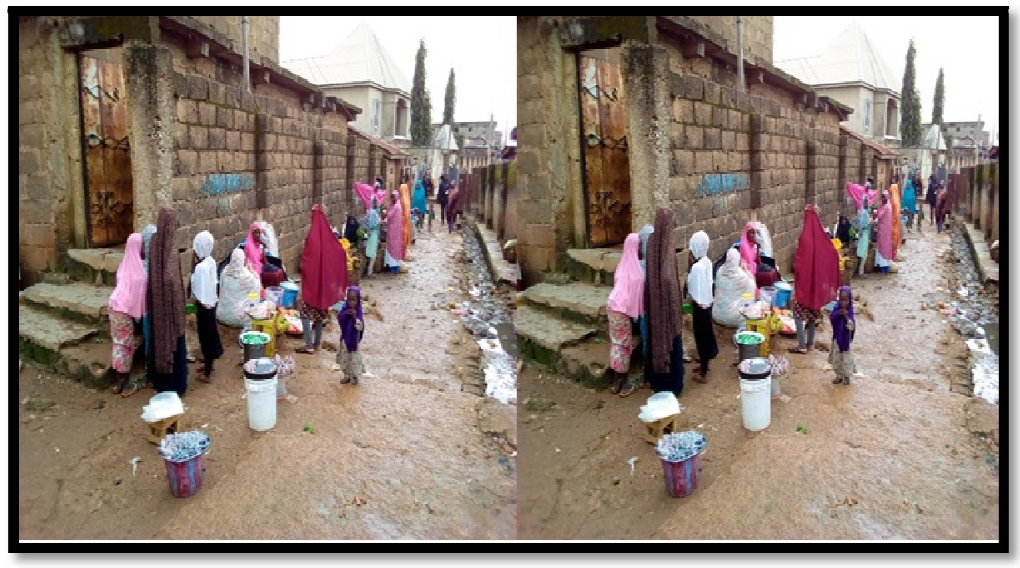

Figure 14: Showing the Slum Dwellers Performing Business

Activities on the Road

Source: Author's Field Survey, 2018

\section{Risk Prevalent in Slums}

\subsection{Violence}

Empirical data recommend crime rates are higher in some slums than in non-slums, with slum homicides alone reducing life expectancy of a resident in a Brazil slum by seven years than for a resident in nearby non-slum (Mehta, 2013). In some countries like Venezuela, officials have sent in the military to control slum criminal violence involved with drugs and weapons (Karl, 2013). Rape is another serious issue related to crime in slums. In Nairobi slums, for example, one fourth of all teenage girls are raped each year (Newer, 2013).

\subsection{Unemployment}

Due to lack of skills and education as well as competitive job markets, many slum dwellers face high rates of unemployment (World Health Organization, 2004). The limit of job opportunities causes many of them to employ themselves in the informal economy, inside the slum or in developed urban areas near the slum. This can sometimes be lawful informal economy or unlawful informal economy without working contract or any social security.

\subsection{Prone to Natural Disasters and Man-Made Hazards}

Slums are often located amongst the places vulnerable to natural disasters such as landslides and floods (Smith, 2013). In cities located over a mountainous terrain, slums begin on slopes difficult to reach or start at the bottom of flood prone valleys, often hidden from plain view of city center but close to some natural water source. In cities located near lagoons, marshlands and rivers, they start at banks or on stilts above water or the dry river bed; in flat terrain, slums begin on lands unsuitable for agriculture, near city trash dumps, next to railway tracks, and other shunned, undesirable locations 
(Rosa, 2011). However, the ad-hoc construction, lack of quality control on building materials used, poor maintenance, and uncoordinated spatial design make them prone to extensive damage during natural disasters.

\subsection{Epidemics}

Slums have been historically linked to epidemics. This trend has continued in modern times. For example, the slums of West African nations such as Liberia were crippled by as well as contributed to the outbreak and spread of Ebola in 2014. Slums are considered a major public health concern and potential breeding grounds of drug resistant diseases for the entire city, the nation, as well as the global community (Alirol et al, 2011).

\subsection{Child Labour and Malnutrition}

According to Ghosh \& Shah, (2004), child labour and malnutrition is more common in slums than in non-slum areas. In Mumbai and New Delhi, $47 \%$ and $51 \%$ of slum children under the age of five are stunted and 35\% and $36 \%$ of them are underweighted. These children all suffer from third-degree malnutrition, the most severe level, according to WHO standards. A study conducted by Tada et al. in Bangkok slums illustrates that in terms of weight-forage, $25.4 \%$ of the children who participated in the survey suffered from malnutrition, compared to around $8 \%$ national malnutrition prevalence in Thailand (Tada et al, 2002). In Ethiopia and the Niger, rates of child malnutrition in urban slums are around 40\% (United Nations Human Settlements Programme, 2006).

\section{Conclusion}

The deplorable state of Anguwan Rogo slums requires urgent attention to ameliorate the harsh and unhealthy conditions experienced by the slum dwellers, it has become imperative to look for the way forward out of the unprecedented growth rate that generated various problems such as unemployment, lack of inadequate social, medical, educational and recreational facilities, inability to manage urban facilities effectively, over- utilization of existing inadequate facilities and environmental deterioration. It is the urgent need to look for a way forward that will lead to the development of slums across cities and urban centers.

\section{Recommendations}

The researchers hereby recommend the following:

- Organizations such as Jos Metropolitan Development Board (JMDB) in the State embark on more awareness of environmental sanitation in line with the mandatory month-end sanitation exercise and enforcement of penalties to defaulters.

- Government to review the housing policy and the Land Use Act to incorporate an enforceable statement for the prevention of force eviction on short notice and without the compensation of affected household.

- Also, the government can create enabling environment to dialogue with the slum residents under which people, using and generating their own resources, could find unique local solutions for their housing and shelter problems.

- Finally, inputs of professionals such as architects, urban designers and town planners should be sought in cases of re-settlement and upgrading schemes.

\section{References}

i. Abubakar, I.R. (2014). Abuja city profile. Retrieved September 3, 2018 from www.elsevier.com/locate/cities.

ii. Adeyinka, S. A., Kuye O. A., \& Agbabiaka H. I. (2016). Assessment of Market Facilities and Locational Effects on Adjoining Neighborhoods in Nigerian Urban Centers: Empirical Evidence from Akure, Nigeria. International Journal of Scientific \& Technology Research 5 (4), 199-206.

iii. Ajiji, D. N. \& Larab, T. A. (2016). The Growth of Urban Slums and Conflicts in Nigeria: A Case Study of Jos and Environs 1980-2010. International Journal of Social Science and Humanity, 6 (5), 364-369.

iv. Arimah B. C. (2001). Slums as expression of social exclusion: Explaining the prevalence of slums in African countries, Paper presented at United Nations Human Settlement Programme, held at Nairobi, Kenya.

v. Babanyara, Y.Y., Usman, H.A., \&Saleh, U.F. (2010). An Overview of Urban Poverty and Environmental Problems in Nigeria.Journal of Human Ecology, 31 (2), 135-143.

vi. Chattopadhyay,S. \& Biswas,A.(2010). Slum Improvement through legal framework in India. International Journal for Housing Science. 34(2), 139-150

vii. Collins English Dictionary. Slum definition and meaning. Retrieved November 23,2018from https:/ / www.collinsdictionary.com/ dictionary/ english/ slum

viii. Dung-Gwom, J. Y. (2007).Urban Renewal in Jos - Bukuru Metropolis. Paper Presented at the Nigerian Institutions of Estate Surveyors and Valuers, MCPD Workshop on: Housing Delivery, Urban Renewal in Jos - Bukuru Metropolis Problems and Prospects.

ix. Emma-Ochu, C. A. \& Onwuka, E. (2016). Slum Development and Urban Renewal in Nigeria. In Ebohon, O. J., Ayeni, D. A, Egbu, C. O, andOmole, F. K. Procs. of the Joint International Conference (JIC) on 21st Century Human Habitat: Issues, Sustainability and Development, 21-24March 2016, Akure, Nigeria, page number 1599-1607

x. Five Largest Slums in the World: The Borgen Project. Retrieved September 10,2018from https:/ / borgenproject.org/ 5-largest-slums-world .

xi. Fwatshak,S. U. \& Dugga,V. S. (2011). "Conflicts and cooperation in the politics of Jos North LGA of Plateau State, Central Nigeria, 1991-2008".Nasarawa Journal of General Studies, 1(1), 55-61. 
xii. $\quad$ Glenday, Craig (Ed.), Guinness World Records 2013, Bantam. pp 277

xiii. Habitat Country Programme Document Nigeria (2017 - 2021). pp 1-39

xiv. Jos: A City Torn Apart: Human Rights Watch (2001). Vol.13 No. 9(A) pp 13-14

xv. Karl R. (2013). Venezuela's military enters high crime slums. Associated Press.

xvi. Lekwot, E.V., Yakubu, A. A., Kwesaba, A.D., \& Sahabo, A.A. (2015). An Analysis of Inner-City Decay: A Study of Some Selected Slums in Jos Metropolis, Plateau State, Nigeria. International Journal of Scientific \& Technology Research 4(2), 171-176.

xvii. Mahabir, R., Crooks, A., Croitoru, A., \& Agouris, P. (2016). The study of slums as social and physical constructs: challenges and emerging research opportunities,

xviii. Regional Studies, Regional Science, 3:1, 399-419, DOI: 10.1080/ 21681376.2016.1229130

xix. Mallo, M. D., Samuel, D. W., Esther, M. A., Choji, C. M.\& Aliyu, A. A. (2015). Slum Housing Conditions and Eradication Practices in Some Selected Nigerian Cities. Journal of Sustainable Development.8(2), 230-241

xx. Morakinyo, K. O., Ogunrayewa, M. O., Koleosho, B. O., \& Adenubi, O. O. (2012). Urban Slums as Spatial Manifestations of Urbanization in Sub-Saharan Africa: A Case Study of Ajegunle Slum Settlement, Lagos, Nigeria. The International Institute for Science, Technology and Education (IISTE).2(3), 1-11.

xxi. Mike Davis, (2006). Planet of Slums. Le pire des mondes possibles: de l'explosion urbaine au bidonville global. La Découverte, Paris, ISBN 978-2-7071-4915-2

xxii. Ogunrayewa, M.O. (2010). Severity Diagnosis of Building Deterioration Factors in Selected Nigerian Universities. Unpublished Ph.D. Thesis, University of Jos,

xxiii. Okoronkwo, N.C. (2017). Proposed landscape re-design for Jos city centre. Unpublished HND Thesis, Federal College of Forestry, Jos.

xxiv. Omole, F. K. (2010). An Assessment of Housing Condition and Socio-Economic Life Styles of

xxv. Slum Dwellers in Akure, Nigeria. Contemporary Management Research. Vol 6. No 4.pp 273-290, 2010.

xxvi. Oladosu, R.O., Bukar A. G., \& Haruna B.B.(2015). Residents' Satisfaction with Public Facilities and Neighbourhood Environment in Slum Residential Areas of Jos, Plateau State, Nigeria. Journal of Environment and Earth Science,5(14), 26-33.

xxvii. Rosa F. F. (2011). Physical and Spatial Characteristics of Slum Territories Vulnerable to Natural Disasters. Les Cahiers d'Afrique de l'Est, $n^{\circ} 44$, French Institute for Research in Africa.

xxviii. Smith \& Keith (2013). Environmental hazards: assessing risk and reducing disaster. Routledge, ISBN 9780415681056 State of the World Cities Report, 2012/ 2013: Prosperity of Cities. Retrieved September 8, 2018.

xxix. Sunday A. B. \& Alexander A. F. Slum Prevalence in Nigeria: What Role for Architects? World Environment. Vol. 3 No. 2, 2013, pp. 45-51. doi: 10.5923/j.env.20130302.02.

xxx. Sustainable Development Goals | UNDP. Retrieved August 12, 2019 from https:/ / www.undp.org/ content/ undp/ en/ home/ sustainable-development-goals.html

xxxi. Sustainable Development Goals. Retrieved August 12, 2019 from https:/ / en.wikipedia.org/ wiki/ Sustainable Development Goals

xxxii. The challenge of slums: global report on human settlements, 2003 / United Nations Human Settlements Programme. Earth scan Publications Ltd.

xxxiii. The Cities Alliance Action Plan, (1999).

xxxiv. The World Bank. (2002). Cities without Slums. Urban Notes 2, 2002.

xxxv. Top Ten Largest Slums in the World 2018.Retrieved September 10, 2018from https:/ / naijaquest.com/ largest-slumsin-the-world.

xxxvi. United Nations -Habitat. (2006). Cities, Slums and Millennium Development Goals. Asia- Pacific Ministerial Conference on Housing and Human Settlements, 2006. Retrieved September 11, 2018 from www.unhabitat.org.

xxxvii. United Nations Human Settlements Programme (2006). State of the world's cities 2006/7. London: Earthscan Publications.

xxxviii. UN-Habitat Report, (2007).Slum Dwellers to double by 2030Archived 2013-03-17 at the Wayback Machine UNHabitat Report, (2012).

xxxix. University of Jos (Rev.ed.), (2017). Guidelines for preparation and submission of theses and dissertations and issues in quality research enhancement. Jos: School of Postgraduate Studies.

xl. Urbanization: Trends, Causes and Effects. Retrieved November 23, 2018 fromwww.open.edu/ openlearncreate/ mod/ oucontent/ view.php?id=79940

xli. World Health Organization (2004). Water, Sanitation and Hygiene Links to Health: Facts and Figures. 